\title{
Does the sexual harassment procedure work?
}

\section{Colleen Hicks*}

One must presume that the parties who placed this procedure in the Labour Relations Act had a specific goal in mind. If we look at the Government Green Paper Industrial relations, a framework for review, volume 2, page 173 , - one of the options with regard to this topic - the one ultimately legislated for is set out as:

To extend the definition of personal grievance to specifically include discrimination in the work place, or alternatively to create a separate grievance procedure to deal with such matters. This option would be attractive in offering all workers covered by awards and agreements an easily accessible, flexible and relatively quick mechanism for resolving such matters close to their point of origin.

The Green Paper goes on to consider what form this grievance procedure should take and to ask some fundamental questions:-

1. Are the existing mediators and conciliators who chair Personal Grievance Committees the appropriate personnel to deal with such cases? It may be felt that quite different skills are required.

2. They went on to consider whether or not the procedure should in some way be shared with the Human Rights Commission, and I do believe that the legislators, while requiring a worker to choose which path the Personal Grievance or Human Rights Commission was to take, may have thought they were introducing some element which would allow the Mediation Service to use the expertise of the Human Rights Commission.

Section 221(b) provides for investigative powers (unusual in grievance committees per $c e$ ) and may have been intended to parallel the investigative powers given to the Human Rights Commission. The power is, I am advised, one that should be reserved for use in unusual or difficult cases, because practical difficulties arise from the natural justice requirements of $s 221$ (b), namely that matters of fact or opinion gleaned from such an investigation have, for fairness sake, to be put to both sides so that they can comment before a decision is made. This means that information proffered in confidence cannot be kept secret and therefore, though the circumstances of a case might cry out for further 
investigation, people must be told before they proffer any information to the committee that such information will not be confidential.

The Human Rights Commission have developed procedures to investigate which have no such stringent requirements. Unlike mediators under the Labour Relations Act, their actions are specifically protected from review by the Courts. This is not so for the Mediation Service, and it can therefore be seen that the principles of natural justice must be uppermost in the mediator's mind when conduct of a committee is being considered. (The grievant will not be assisted by having a case overturned on review and indeed may have to go back to square one). This leads to a requirement for examination and crossexaminations of witnesses, including the grievant - something which can be a somewhat brutalising experience and which, on a misapprehension as to how the procedures would work, I find in the first few cases that the union has assumed their member would not have to face.

There have been, by my best estimate, approximately seven cases throughout New Zealand brought under these procedures. Given that the Act is now more than a year old, this is not the flood of complaints that we were expecting. Why is this so? I have already alluded to one of the main reasons but there are others.

First, the definitions. They do not cover the most frequent form of sexual harassment - a matter which I will explore shortly.

Second, one of the most frequent forms of sexual harassment is that carried out by fellow workers. The requirement for the grievant to put the complaint in writing I see as a further impediment as a harassed worker is likely to be inhibited by the situation they find themselves in and are most unlikely to commit the matter to writing in the first instance. Failure to carry out this step is an impediment to further action.

I would like now, briefly to look at the deficiencies as I perceive them in the definitions. I understand that the definition that would have covered the concept of "hostile environment" was specifically not contemplated by those who drafted the Act. By "hostile environment" I mean the sort of case which has recently succeeded in New York. There, female firefighters were constantly harassed by male workers with such objectionable behaviour as finding their "boots had been pissed in" by their fellow male firefighters. Such actions by New Zealand firemen against a female worker would not be covered by our present definitions. I have had a case in New Zealand where a worker who was thought to be a bit "straight-laced" by her fellow male workers suffered behaviour, which I will not detail, of similarly abhorrent nature, but because there was no request for sexual favours or any such intent, the definitions as set out did not cover the case.

Finally, I would like to comment briefly on my experience of chairing these meetings and to contrast this with the objectives [of the grievance procedure] as set out in the aforementioned Green Paper: The case I shall talk about, without identifying names, is the recent and indeed the only sexual harassment case as yet considered by the Labour Court, i.e. The Northern Industrial District Distribution Workers and Hawkes Bay Province Stores, Packing and Warehouse Workers Industrial Union of Workers v A.B. Limited.

The union came with a 16 year old grievant and the employer came with his lawyer. The employer was very angry and the union had already told the grievant that she would not have to front up to the employer. Not only was this not the case, but she found herself questioned by legal counsel. The union objected. After much discussion between the parties the following solution was arrived at.

When it came to cross-examination, the lawyer wrote down his questions and I posed them to the grievant and wrote down her answers word for word and the lawyer then asked supplementary questions which I carried through the same process. This was very laborious. In the event, I was left to decide the matter. I was faced with an absolute denial on the part of the employer and no corroborative evidence. Faced with a clear conflict of evidence and having no-one on oath, and a somewhat strange procedure which had not enabled me to get at the truth, I did the only thing I could; I sent the matter to 
Court. There the grievant had no choice but to undergo cross-examination and all that it implies.

I note also that the judge was somewhat scathing of the actions of the union in instructing the grievant not to return to work and so breaching the employment relationship.

I must say that I felt that the union had lacked finesse in dealing with what is a very delicate situation. The grievant was awarded $\$ 3,000$ but she still has no job and in that small country town no likelihood of one. I can't help but think that handled differently she could have had both her job and an environment made safe from sexual harassment.

It is a perfect example of the application of a blunderbus where the expertise and counselling of the Human Rights Commission might have been more appropriate.

Indeed, I believe that most union organisers are coming to grips with the difficulties manifest in using these procedures and determining that slow and toothless or not, the Human Rights Commission may be the more appropriate body to deal with these grievances. The Human Rights Commission tell us that there has been a great jump in their work load of sexual harassment cases.

To return to what was expected of these procedures when they were legislated for:-

1. Easily accessible. It being relatively simple to set up a Grievance Committee certainly it is easily accessible but whether or not that makes it easily accessible to the workers who is actually suffering harassment, I have my doubts.

2. Flexible. It is certainly not. Note the problems with clear terms and the need to use a union.

3. Relatively quick. Well, certainly it is quick. A grievance hearing of this nature is likely to take no more than four or five hours at the most whereas the Human Rights Commission tell us that a single complaint may lead to investigation which can take as much as ninety hours before the matter is settled, and about all I can say about the procedure that is good, it would seem, is that it is quick.

I am left with grave doubts as to whether the grievance procedure within the Labour Relations Act is the appropriate place for these matters to be dealt with, or whether, indeed, the Mediation Service which is tied into a somewhat confrontational framework, is the place for these matters to be dealt with. 


\section{IN FORTHCOMING ISSUES:}

The Changing Importance of Lifetime Jobs

SUSAN B. CARTER

Quality Circle Survival: An Exploratory Analysis

ROBERT DRAGO

Mechanisms of Labor Management, Unionization, and the Potential for Representation JOHN EVANSOHN

The Impact of Internal Union Politics on the 1981 UMWA Strike

TERESA GHILARDUCCI

Corporate Characteristics and Union Organizing

CHERYL L. MARANTO

Economic and Political Factors in the Resolution of Formal Grievances

DAVID MEYER and WILLIAM COOKE

Relative Hours of Part-Time and Full-Time Workers at the Same Firm MARK MONTGOMERY

Labor Relations, Wages, and Nonwage Compensation in Municipal Employment JEFFREY S. ZAX

Published in Winter, Spring, and Fall. Annual subscriptions: Institutions $\$ 27.50$ (North America), $£ 22.00$ (UK), $£ 25.00$ (Overseas). Individuals $\$ 15.00$ (North America), $£ 15.00$ (UK), $£ 15.00$ (Overseas). 